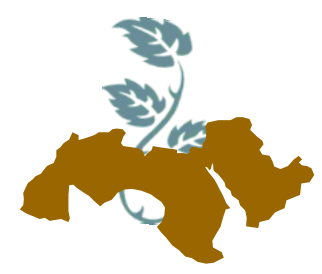

\title{
EFFECT OF SOLAR DRYING ON THE QUALITY OF CORN SEEDS
}

\author{
Gehad, A. Abdalgawad"; M.F. Abdel-Salam²; Magda M. Mosa ${ }^{1}$ \\ and M.M. Mostafa ${ }^{2}$ \\ 1- Agric. Eng. Res. Inst. (AERI), Agric. Research Center, Giza, Egypt \\ 2- Agric. Eng. Dept. Fac. of Agric., Ain Shams Univ., Cairo, Egypt
}

Keywords: Drying process, Solar energy, Sun drying, solar drying, Seeds production, Corn drying

\section{ABSTRACT}

The main objective of this investigation was carried out to study the ability of utilizing greenhouse solar dryers for drying of corn in order to obtain the best quality of dried grains for using it as seeds with the least drying time, and comparing with the natural sun drying method. Thus, contributing to increase the productivity. Corn cv. (Giza 168) was used for the experimental work at initial moisture content of $31.73 \%$ on dry basis (d.b). Two different drying methods of corn were tested for drying of ear and shelled corn. The two methods were natural sun drying and solar drying using greenhouse type solar dryers at different air velocities $(0.5,1.0$ and $1.5 \mathrm{~m} / \mathrm{s})$. The experiments were carried out in rice mechanization center at Meet ElDyba, Kafr El-Sheikh Governorate, Egypt during September 2016.

\section{Experiment included the flowing variables}

1. Two different drying methods (Solar drying method using greenhouse type solar dryer and natural sun drying method).

2. Two different conditions of corn (complete earshelled corn).

3. Three different air velocity $(0.5,1.0$ and 1.5 $\mathrm{m} / \mathrm{s})$.

High moisture ear and shelled corn was dried

by using solar energy for heating air inside a greenhouse and compared with natural sun drying method.

The results of quality tests that included standard germination test, vigor test and tetrazolium test for both drying methods for ear and shelled corn recorded high percentages for all treatments except solar drying of ear corn at air velocities 0.5 and $1.0 \mathrm{~m} / \mathrm{s}$. The average air temperature inside the solar dryer at air velocities 0.5 and $1.0 \mathrm{~m} / \mathrm{s}$ reached to 43.9 and $42.4{ }^{\circ} \mathrm{C}$ respectively. High temperatures killed the germ of corn so the quality tests were reduced. Germination percentage of natural sun dried ear corn was $97 \%$ and for solar dried samples at air velocities $0.5,1.0$ and $1.5 \mathrm{~m} / \mathrm{s}$ was 79,81 , and $89 \%$, respectively. The corresponding values for shelled corn were 93, 97 and $98 \%$.and $95 \%$ for natural sun dried ones. The vigor test of dried ear corn recorded 90 for natural sun drying method and 34,45 , and $66 \%$ for solar drying at air velocities of $0.5,1.0$ and $1.5 \mathrm{~m} / \mathrm{s}$, respectively. The corresponding values for shelled corn were 86,96 and $97 \%$ respectively, and 82 for natural sun dried samples. The recorded drying times were 26, 24 and 28 hours to reduce the moisture content from an initial level of 31.73 to final level of $14.07 \%$ (d.b.) for ear corn and for shelled corn were 20, 16 and 24 hours to reduce the moisture content from an initial level of an initial level of 31.73 to final level of $14.07 \%$ (d.b.) for ear corn and for shelled corn were 20, 16 and 24 hours to reduce the moisture content from an initial level of $27.23 \%$ to $14.12 \%$ compared with 46 and 38 hours for ear and shelled corn dried by natural sun drying method.

Hourly costs of ear corn drying were $0.95,0.88$, 1.00 and $1.03 \mathrm{~L} . \mathrm{E} / \mathrm{kg}$ for solar drying at air velocities $0.5,1.0,1.5 \mathrm{~m} / \mathrm{s}$ and natural sun drying respectively. The corresponding values for shelled corn were $0.74,0.58,0.89$ and $0.96 \mathrm{~L} . \mathrm{E} / \mathrm{kg}$.

\section{INTRODUCTION}

Drying is an excellent way to preserve food. It preserves foods by removing enough moisture 
from food to prevent decay and spoilage (Ajay et al 2009). In Egypt, natural sun drying is one of the most common ways to conserve agricultural products; the food is dehydrated when it is exposed directly to solar radiation.

The moisture is carried away by wind as it blows above the product. There are losses may occur during natural sun drying due to various influences, such as rodents, birds, insect storms and microorganisms. The quality of the dried products may also be significantly lowered (Kamal, 1991).

Solar-drying technology offers an alternative which can process the vegetables and fruits in clean. It saves energy, time, occupies less area, improves product quality, makes the process more efficient and protects the environment (Sharma et al 2009).

Corn (Zea Mays L.) is one of the most important strategic cereal crops in Egypt. In 2015, about 2259730 faddans were planted with white and yellow single and three -way crosse and a total production of about 7057735 tons according to Bulletin of the agricultural satistics (20142015). It is widely used in bread making in rural areas of the country. Recently, maize flour is mixed with wheat flour by $20 \%$ in bread making in order to reduce amount of the imported wheat. Maize grains are the main component of animal and poultry feed production since it represents about $70 \%$ of components. In addition, it is used in silage production. It is also used in oil extraction and in some other industrial purpose such as starch and fructose (Field Crops Research Institute, 2014).

For seeds production, the grains must not expose to high temperature, which it would kill the germ so the air temperature for drying maize must not exceed $42-43^{\circ} \mathrm{C}$ (FAO, 1982)

Sturton et al (1981) reported that high drying temperatures can adversely affect the viability and quality of grains and seeds.

Peplinski et al (1989) studied two methods of drying corn, the first was using ambient air at $25^{\circ} \mathrm{C}$ and the second method was using air heated to 60 ${ }^{\circ} \mathrm{C}$. The results showed that increasing drying air temperature from 25 to $60{ }^{\circ} \mathrm{C}$ had no effect on kernel chemical makeup or test weight but lowered germination up to $10 \%$.

Mohamed (2000) mentioned that corn is usually harvested at a relatively high moisture levels to minimize field losses and give a chance to clear the field earlier after ripening and helps serving and preparing the field for the next crops.

Kamal and El-Kholy (2002) developed a greenhouse solar dryer. The dryer was tested and evaluated for drying high moisture ear and shelled maize variety and compared with natural sun dry- ing method. The results showed that the development of dryer was able to dry ear maize from an initial level of $29.85 \%$ to final level of $14.26 \%$ in 84 $\mathrm{h}$ as compared to $187 \mathrm{~h}$ for sun drying method. The corresponding drying times for shelled maize from an initial grain moisture level of $19.87 \%$ to $14.13 \%$ were $18 \mathrm{~h}$ and $34 \mathrm{~h}$ respectively. The grain germination tests showed an average percentage of over $90 \%$ for both solar and natural sun drying methods of ear and shelled corn.

El-Kholy (2003) developed and evaluated a simple natural convection solar dryer for drying high moisture rough rice. The dryer was used a solar heated air passing by natural convection through a bed of paddy, and from solar radiation incident on the top of the bed. The results showed a significant improvement to final quality of grain dried by the solar dryer compared with the grain dried in open mats specially broken percentage of milled rice

Gebreil (2008) reported that, an improved technology in utilizing solar energy for drying grains in the use of solar dryers where the air is heated in a solar dryer and then passed through grain bed. The greenhouse type which is facilitated with metal frame covered with plastic film, wire netting for floor, fans and duct for air suction to give a required air flow rated was investigated under Egyptian conditions and it was considered a more economic method compared with the artificial drying of agriculture crops.

FengWei et al (2010) designed a solar heating air system for maize ear drying. Experiments showed that system could dry maize ear in short time. It could save $18 \mathrm{~h}$ when compared with traditional drying technology and average drying rate was also proved to $60.8 \%$.

Kiremire et al (2010) studied the effects of sun drying, solar drying and oven drying on the nutrients composition of selected vegetables. The results showed that some nutrients were lost during the drying process but in general, the nutrient content remained high. With respect to retention of the nutrient content in vegetables, solar drying was found to be the best of the three methods and it is recommended as a method for vegetables preservation.

Hellevang (2011) stated that corn above $21 \%$ moisture should not be dried using natural air and low temperature drying to minimize corn spoilage during drying. Adding heat does not permit drying wetter corn and only slightly increase drying speed. The primary effect of adding heat is to reduce the corn moisture content.

Vijaya et al (2012) stated that the best alternative to overcome the disadvantages of traditional open sun drying and the use of fossil fuels is the development of solar crop dryers. In addition to 
mitigation of fossil fuels, the quality of the dried crops is also higher and the loss of dried products is considerably reduced.

Aravindh and Sreekumar (2015) reported that, drying is one of the most prevailing methods of food preservation, where the moisture is removed preventing the growth of micro-organisms that causes food damage. This method helps in reducing the weight and volume of the product which reduces the transportation and storage load and also helps in storing the food in ambient temperature. The moisture content of the product to be dried is an important factor for determining the quality of the product and thereby the market value. Products with higher moisture content are found to have lesser drying time than those having very lesser moisture content. It is because the higher moisture content product may have better mass flow of the moisture from the interior of the product to the surface so that it is removed where the one with lower moisture content may have a thick outer skin.

The main object of this study was studying the ability of utilizing greenhouse solar dryers for drying of corn in order to obtain the best quality of dried grains for using it as seeds with the least drying time, and comparing with the natural sun drying method.

\section{MATERIALS AND METHODS}

\section{Preparation of sample}

Corn (Giza 168) was used for the experimental work at initial moisture content of $31.73 \%(d . b)$ which harvested at Meet El-Dyba, Kafr El-Sheikh Governorate during the 2016 corn harvesting season. The capacity of a solar dryer was $60 \mathrm{~kg}$ of complete ear corn and $48 \mathrm{~kg}$ of shelled corn.

\section{Solar drying method}

Three identical dryers were used in this study as shown in Plate (1). The dimensions of the solar dryer are shown in Fig. (1). The frames of dryer were constructed from iron galvanized pipes of $12.7 \mathrm{~mm}$ and installed on the circumference of four walls forming a batch. The frames of pipes were covered by a clear plastic film. Wire netting constitutes a floor at the bottom of the batch, a black plastic wire net covering the surface of the drying chamber was used as a solar absorber and protected the grains from direct exposure to solar ra- diation. Suction fan of air was fixed at one side of the dryer and driven by electric motor of $0.5 \mathrm{hp}$., and the other side of the dryer has an open window for air inlet of $35 \times 10 \mathrm{~cm}$ and a front door of $70 \times 45 \mathrm{~cm}$ is located at the front of side the dryer for loading, unloading and collecting samples of corn grains as shown in Fig. (1).

\section{Measurements}

The experiments were carried out in rice mechanization center at Meet El- Dyba, Kafr ElSheikh Governorate, Egypt during September 2016 and the following measurements were recorded hourly from 8 a.m. to 6 p.m .

1. Solar radiation in and out the dryer

2. Air velocity

3. Air temperature and relative humidity inside and outside the dryer

4. Ear and shelled corn temperature

\section{Solar radiation in and out the dryer}

A pyranometer sensor model $\mathrm{H}-201$, made in Japan was used for measuring the solar radiation. It was connected to a chart recorder model YEW 3057 in order to convert the voltage single to an equivalent reading in $\mathrm{kW} . \mathrm{h} / \mathrm{m}^{2}$. Its short wave sensitivity $7.0\left(\mathrm{mV} / \mathrm{Kw} \cdot \mathrm{m}^{2}\right)$.

\section{Air velocity}

Anemometer model no. 37000-00, cole pormer instrument company, Vernon Hill, Illinois 600611844, made in USA was used to measure the inlet air velocity over the surface of grains drying bed with an accuracy of $0.01 \mathrm{~m} / \mathrm{s}$.

\section{Air temperature and relative humidity inside and outside the dryer}

Digital temperature and humidity meter, model Chino (HN-K) was used to measure the air temperatures and relative humidity inside and outside the dryer.

\section{Ear and shelled corn temperature}

Thermocouples of copper-constant (T-type) were used to measure the bulk temperature of grains in different places. It was connected to a chart recorder model YEW 3057 in order to read air temperature in ${ }^{\circ} \mathrm{C}$. 


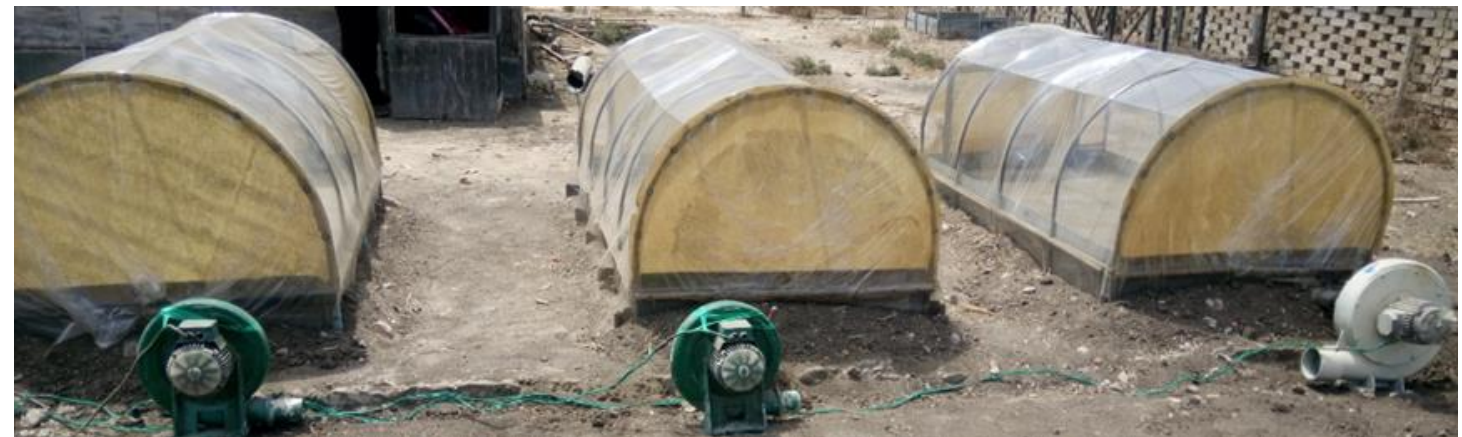

Plat 1. The three identical dryers using in this study
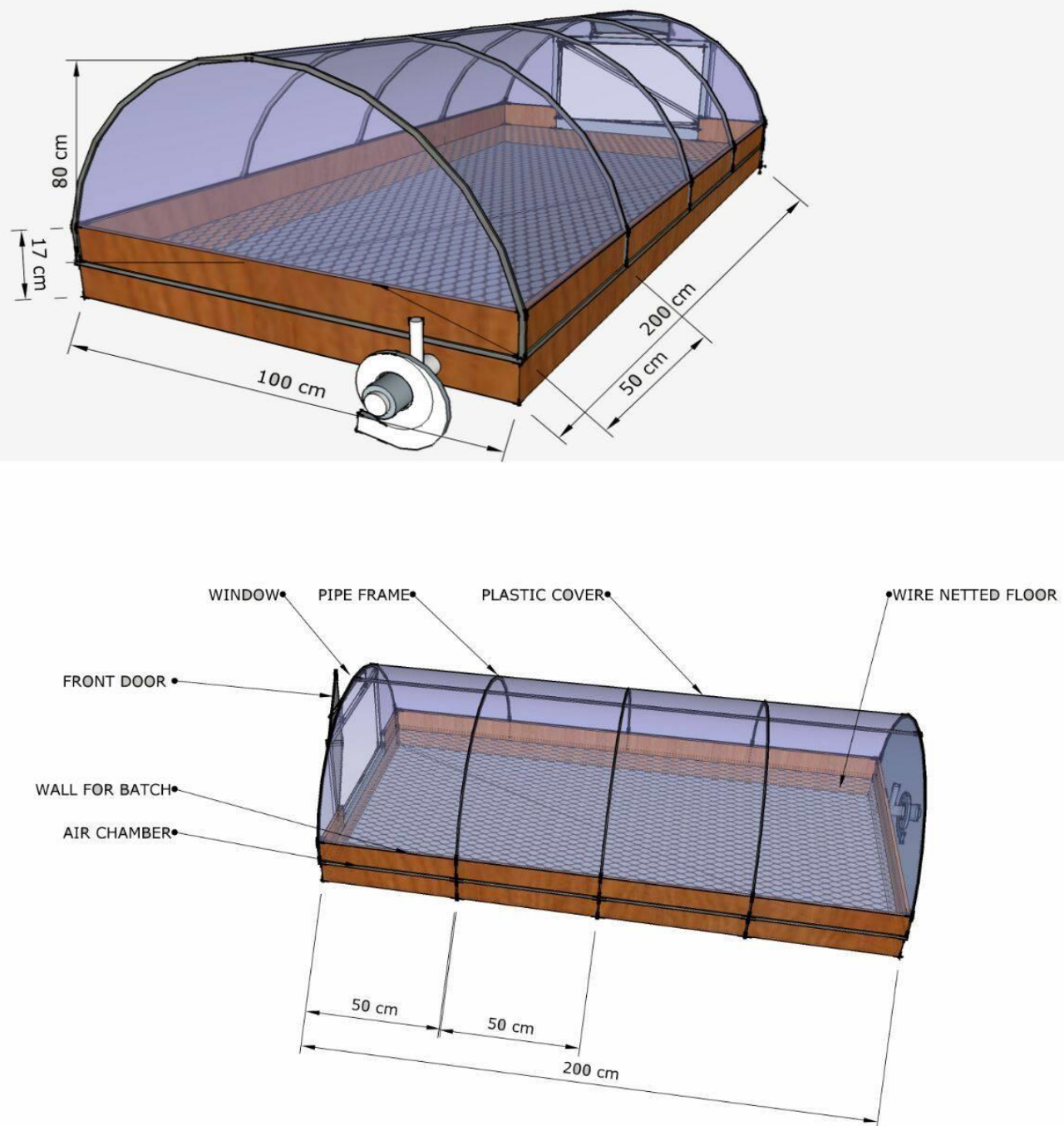

Fig. 1. Schematic of solar greenhouse dryer 


\section{Estimations and calculations}

1. Moisture content

2. Drying rate

3. Drying efficiency

4. Quality tests of dried grain

5. Cost analysis

\section{Moisture content}

The moisture content of grain was calculated by the standard oven method. The samples were taken before and during the drying and weighted before and after set in oven at $130^{\circ} \mathrm{C}$ for 16 hours according to (AOAC, 1990).

\section{Electrical oven}

It was used to dry sample and then determine the moisture content of grains.

\section{Electrical digital balance}

An electrical digital balance was used to measure the mass of wet and dry sample to calculate the moisture content with an accuracy of $0.01 \mathrm{~g}$ and the maximum mass was $3000 \mathrm{~g}$.

The moisture content was calculated as a dry basis as follow according to (Reeb and Milota, 1999):

$$
M c=\frac{\text { Initial weight }- \text { final weight }}{\text { final } w e i g h t} * 100
$$

\section{Drying rate}

$$
\text { Drying rate }(K g / h)=\frac{\left(M_{t+d t}-M_{t}\right)}{d t}
$$

\section{Where:}

$\mathbf{M}_{\mathbf{t}}$ : Moisture content ( $\mathrm{Kg}$ water/ $\mathrm{Kg}$ dry matter) at time $\mathrm{t}$.

$\mathbf{M}_{\mathrm{t}+\mathrm{dt}}$ : Moisture content ( $\mathrm{Kg}$ water/ $\mathrm{Kg}$ dry matter) at time $\mathrm{t}+\mathrm{dt}$.

dt : Time difference, $\mathrm{hr}$

\section{Drying efficiency}

According to ASHRAE (2005), the drying efficiency $\left(\eta_{d}\right)$ is the ratio of energy required to evaporate the moisture from the corn to the solar radiation flux incident and received over the surface area of the drying bed as follow:

$$
\eta_{d}(\%)=\frac{Q_{e v}}{R A_{d}} * 100
$$

Where:

$\boldsymbol{Q}_{\boldsymbol{e v}}$ : Thermal energy utilized for drying, W.

$\mathbf{R}$ : The solar radiation flux incident inside the solar dryers, $\mathrm{W} / \mathrm{m}^{2}$

$\mathbf{A}_{\mathbf{d}}$ : The net surface area of the drying chamber, $\mathrm{m}^{2}$.

The total thermal energy used for drying corn includes the following parameters; sensible heat used to raise the temperature of corn $\left(q_{\text {sensible }}\right)$, and the latent heat energy used to vaporize the water from the corn $\left(q_{\text {latent }}\right)$, could be calculated as follow

$$
\begin{gathered}
Q_{e v}=q_{\text {laten }}+q_{\text {sensible }}, \text { Watt } \\
Q_{e v}=\frac{L_{h} m_{w}+m_{i} c_{p c}\left(T_{a i}-T_{c}\right)}{3.6}, \text { Watt } \\
m_{w}=\frac{m_{i}\left(M_{i}-M_{f}\right)}{\left(100-M_{f}\right)}, K g
\end{gathered}
$$

\section{Where:}

$L_{h}$ : The latent heat of vaporization of water in corn, $\mathrm{Kj} / \mathrm{Kg}$.

$\mathbf{m}_{\mathbf{w}}$ : Mass of water evaporated from the corn during the drying process, $\mathrm{Kg}$.

$\mathbf{m}_{\mathbf{i}}$ : Mass of corn in the dryer, $\mathrm{Kg}$.

$\mathbf{C}_{\mathrm{pc}}$ : Specific heat of corn, $\mathrm{KJ} / \mathrm{Kg} .{ }^{\circ} \mathrm{C} .(2.13 \mathrm{KJ} / \mathrm{Kg}$.

${ }^{\circ} \mathrm{C}$ ) as mentioned by Meiering et al 1977).

$\mathbf{T}_{\mathrm{ai}}$ : Air temperature inside the dryer, ${ }^{\circ} \mathrm{C}$

$\mathbf{T}_{\mathrm{C}}$ : Bulk temperature of corn, ${ }^{\circ} \mathrm{C}$.

$\mathbf{M}_{\mathbf{i}}$ : Initial moisture content of drying load, \% w.b.

$\mathbf{M}_{\mathbf{f}}$ : Final moisture content of drying load, \% w.b

\section{Quality tests of dried grain}

Common tests for determination the of quality of dried grain for using as seeds are standard germination test, vigor test and Tetrazolium test (viability test) according to central administration for seed certification.

\section{Standard germination test}

The test is done according to ISTA rules (INTERNATIONAL SEED TESTING ASSOCIATION) and also (MD 368/1998- article 3). The main purpose of this test is to determine the percentage of the germination for seed samples.

The test is done to determine the germination capacity of the seed lot under testing also to com- 
pare the quality of various seed lots and to determine the amount of cultivation value. It could not be possible to control the germination test under the normal conditions

in the field while doing the germination test by using the laboratory methods is controlled against the external conditions that are presented more reliable and faster germination results for the species being tested. Germination test is done under optimum conditions of substratum, temperature, moisture, light and air. In certain cases, seeds require especial treatments to break the dormancy or to promote the germination as in the rules.

Corn samples were divided into 100 kernel sub-samples in three replicates. Samples of each replicate were surface sterilized using $2 \%$ sodium solution and rinsed three times using distilled water. Germination tests were replicated three times in petri dishes containing moistened filter paper for a week the corn kernel having both roots and shoots were considered germinated.

\section{Vigor test}

The original purpose of this test was to predict the life of seed in storage. Forty $\mathrm{ml}$ of water added to each plastic box and the wire mesh tray is placed in the box. Seed samples are determined on a weight basis and are placed in the tray (approximately one layer deep). The amount of seed weighted for each crop will depend on the size of the crop and cultivar. Large seeded crops such as corn may require two or more boxes per sample to get the necessary seed for testing while maintaining the one layer in the tray. The lid is secured on each box and the inner chamber (containing box, water, wire mesh tray and seed) is placed into an incubator. The aging time and temperature for corn is 96 hours and $42{ }^{\circ} \mathrm{C}$. The incubator should not be opened during the aging period. Following the aging period, the seed samples are removed and planted under the conditions recommended for the standard germination test for the corn (AOSA, 1986) but usually with only 4 replications of 50 seeds. When aging is initiated for many seed lots on the same day, the samples should be grouped at approximately one hour intervals to allow planting immediately after the aging period. Accelerated aged seeds are germinated and evaluated according to the AOSA.

\section{Tetrazolium test (TZ test)}

The main purpose of the tetrazolium test (viability test) is to distinguish viable and non-viable seeds. Whether a seed is rated viable or nonviable is derived directly from the importance of different seeds tissues responsible for the emergence and development of a normal seedling, which is species specific. Viable seeds are those that show the potential to produce normal seeding. Such seeds stain completely, or if only partly stained, the staining patterns indicate that essential structures are viable.

Non-viable seeds are those that do not meet these requirements and in addition include seeds which reveal uncharacteristic coloring and flaccid essential structures. Seeds with obviously abnormal development of the embryo or other essential structures shall be regarded as non-viable whether stain or not. Rudimentary embryos of coniferous seeds are non-viable.

Grains soak 18 hours in water at $20^{\circ} \mathrm{C}$. The preparation before staining include cut grains longitudinally through embryo and $3 / 4$ of endosperm as shown in Fig. (2), then staining 2 hours at $30^{\circ} \mathrm{C}$ in $1.0 \%$ TZ-solution. The preparation for evaluation includes spread grain into two halves and observe cut surface. The evaluation stage (maximum area of unstained, flaccid and necrotic tissue permitted) observe the primary root in total $1 / 3$ of the area of the margin scutellum, an unstained tissue at the center of scutellum is indicative of heat damage as shown in Fig. (3). (ISTA, 2011).

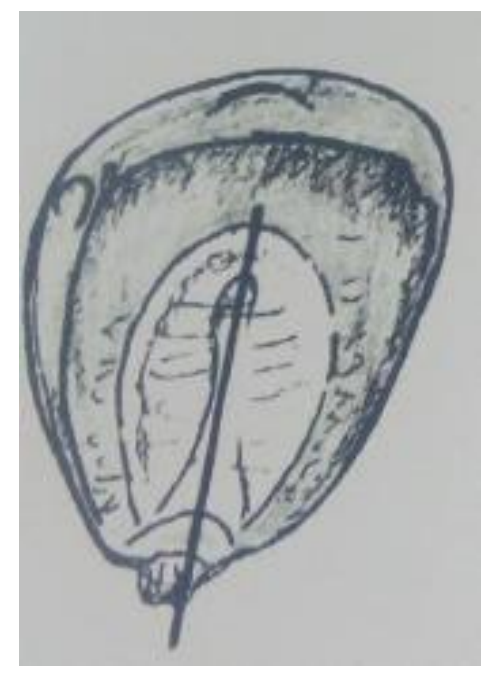

Fig. 2. Grain preparation before testing(cut longitudinall). 


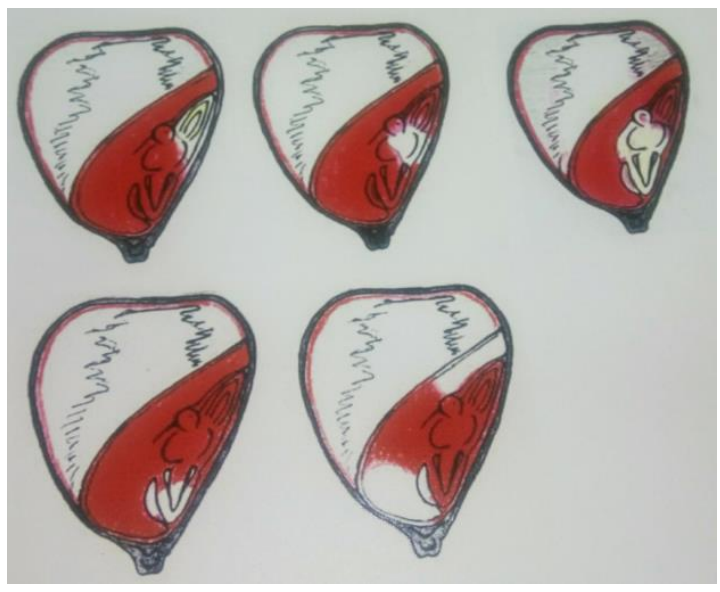

Fig. 3. Test evaluation and examples of non-viable seeds.

\section{Cost analysis}

The hourly cost of drying was included fixed costs and operating costs as mentioned by (FMO, 1975). The parameters which are considered while cost evaluation of drying are presented in Table (1).

\section{Fixed costs}

1- Depreciation, (L.E/year) $=$

$\underline{\text { Original cost }- \text { Salvage value }}$ Mechanical life

Salvage value is $10 \%$ of original cost

2- Interest, (L.E/year) $=$ Interest rate $\times$

$\frac{\text { Original cost }+ \text { Salvage value }}{2}$

Interest rate is $12 \%$

3- Shelter, taxes and insurance, (L.E/year) = $4.5 \%$ × original cost

Total fixed cost, $($ L.E/h) $=$

Depreciation + Interest +

Shelter, taxes and insurance hour of use per year

\section{Operating costs}

1- Repair and maintenance, (L.E/h) =

\section{0\% Deprecication cost \\ hour of use per year}

3- Electricity, (L.E/h).

Total operating cost, $($ L.E/h) $=$

Repair and maintenance + Labour + Electricity 12

Total costs, $($ L.E/h) $=$

Fixed costs + Operating costs

Total costs, $(\mathrm{L} . \mathrm{E} / \mathrm{Kg})=$

$$
\frac{\text { Total costs, }(\mathrm{L.E} / \mathrm{h})}{\text { Productivity, }(\mathrm{Kg} / \mathrm{h})}
$$

Table 1. The parameters which are affecting on costs evaluation of drying

\begin{tabular}{|l|c|}
\hline \multicolumn{1}{|c|}{ Parameter } & Value \\
\hline Price of dryer, L.E & 2000 \\
Operational life of dryer, year & 10 \\
Operational hours & 900 \\
Labour for ear corn drying, L.E/h & 5 \\
Labour for shelled corn drying, & 20 \\
L.E/h & 0.2997 \\
Electricity for suction fan, L.E/h & 0.5994 \\
Electricity for shelling machine, \\
L.E/h $\quad$ RESULTS AND DISCUSSION \\
According to 2016 price "\$ = 12.85 L.E"
\end{tabular}

\section{Solar radiation}

The values of solar radiation varied from hour to hour due to climate conditions, variation in solar altitude angle from early morning to late afternoon and solar incident angle. Solar radiation gradually increased from sunrise till reaches the maximum average value to $1068.571 \mathrm{~W} / \mathrm{m}^{2}$ and 1191.481 $\mathrm{W} / \mathrm{m}^{2}$ at the time of 12 noon for ear and shelled corn drying period respectively, then decreases gradually till it reaches to the minimum values of $121.429 \mathrm{~W} / \mathrm{m}^{2}$ and $131.429 \mathrm{~W} / \mathrm{m}^{2}$ at 6 p.m. for ear and shelled corn drying period respectively. As

10 shown in Fig. (4), the actual solar radiation inside the solar dryer was lower than that outside the dryer due to the reflectivity, absorptivity and transmissivity of the solar dryer covering material.

2- Labour, (L.E/h). 


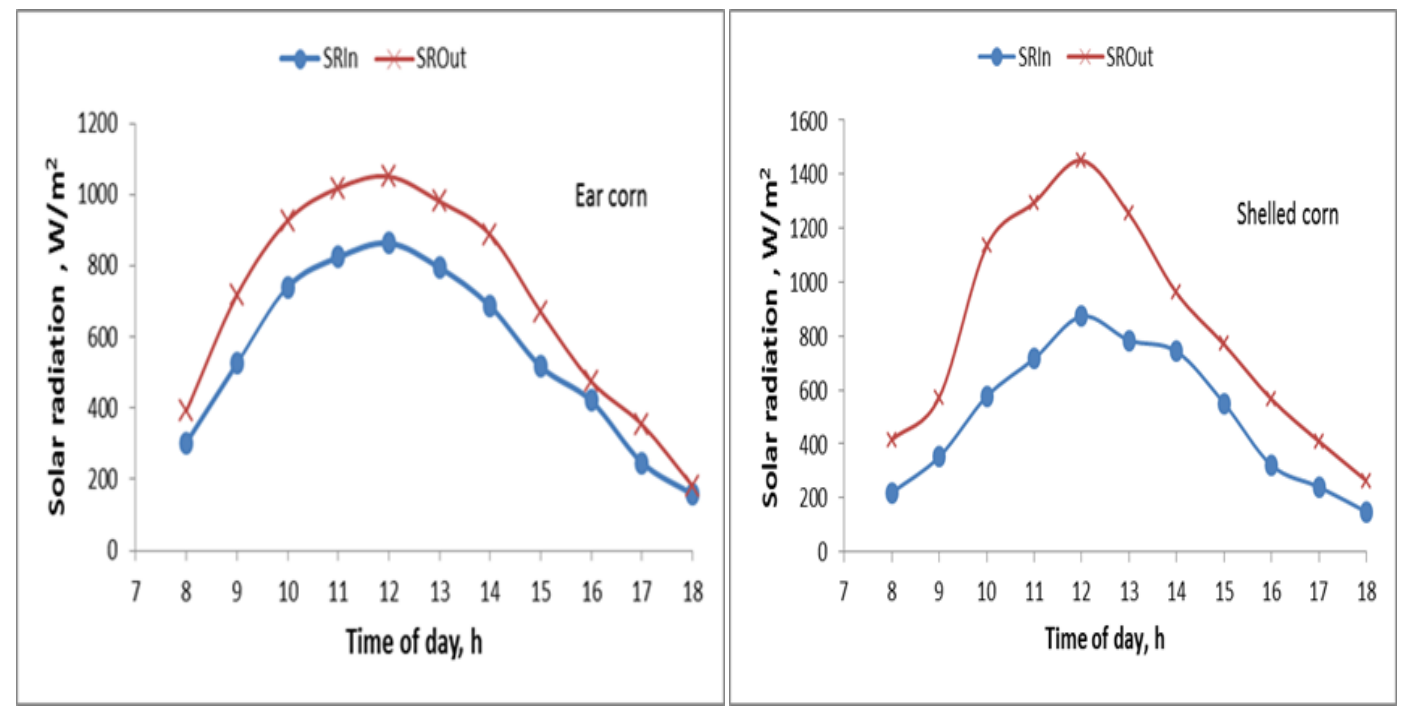

Fig. 4. Average hourly solar radiation flux inside and outside the dryer during drying ear corn and shelled corn. (2/9-10/9 2016)

\section{Air temperature and relative humidity}

Air temperature and relative humidity inside the solar dryer are affected by the air velocity inside the dryer. Increasing the air velocity, the air temperature inside the dryers decreased and relative humidity increased. When air passes through dryers at air velocities of $0.5,1.0$ and $1.5 \mathrm{~m} / \mathrm{s}$, the solar dryer can increase the air temperature by 11.02 , 9.51 and $7.11{ }^{\circ} \mathrm{C}$, respectively. The relative humidity can decrease by, 13.09, 12.26 and $10.36 \%$ at air velocities $0.5,1.0$ and $1.5 \mathrm{~m} / \mathrm{s}$, respectively as shown in Figs. (5 and 6).

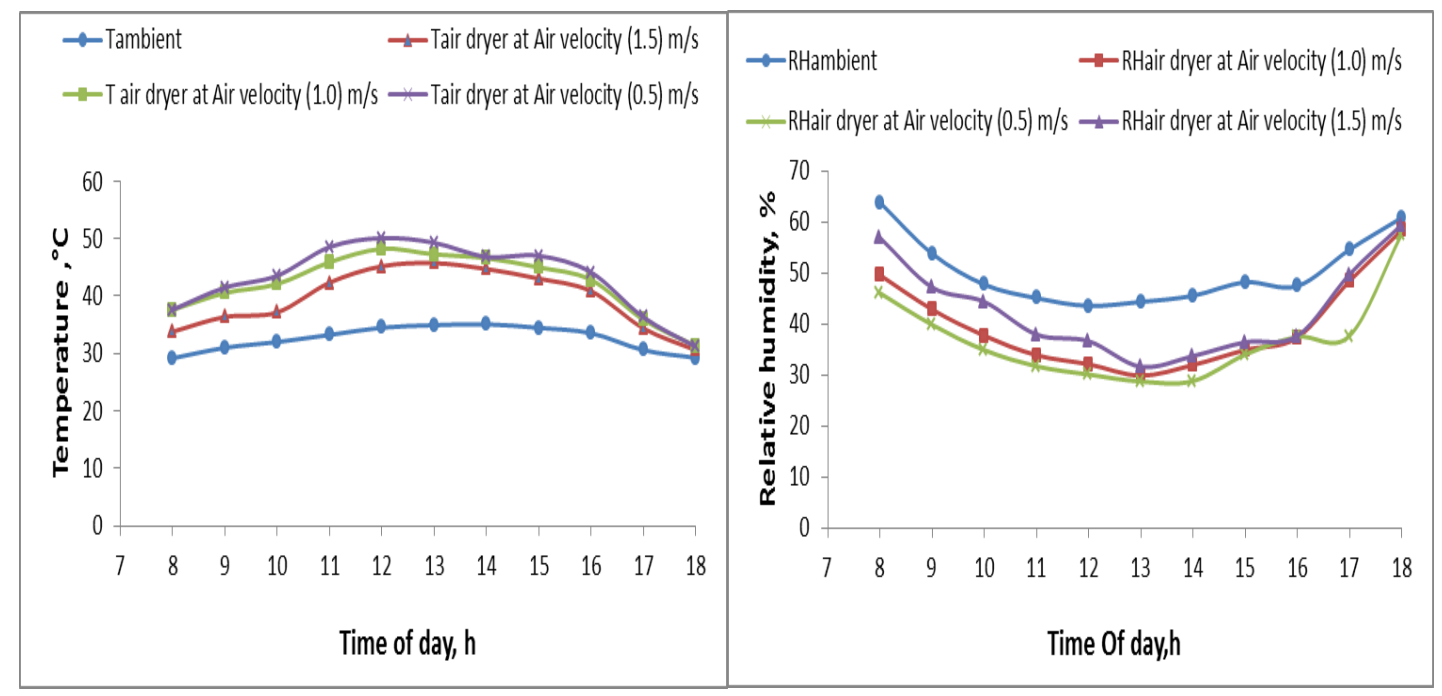

Fig. 5. Average air temperature and relative humidity inside and outside the dryer during the period of drying ear corn. 


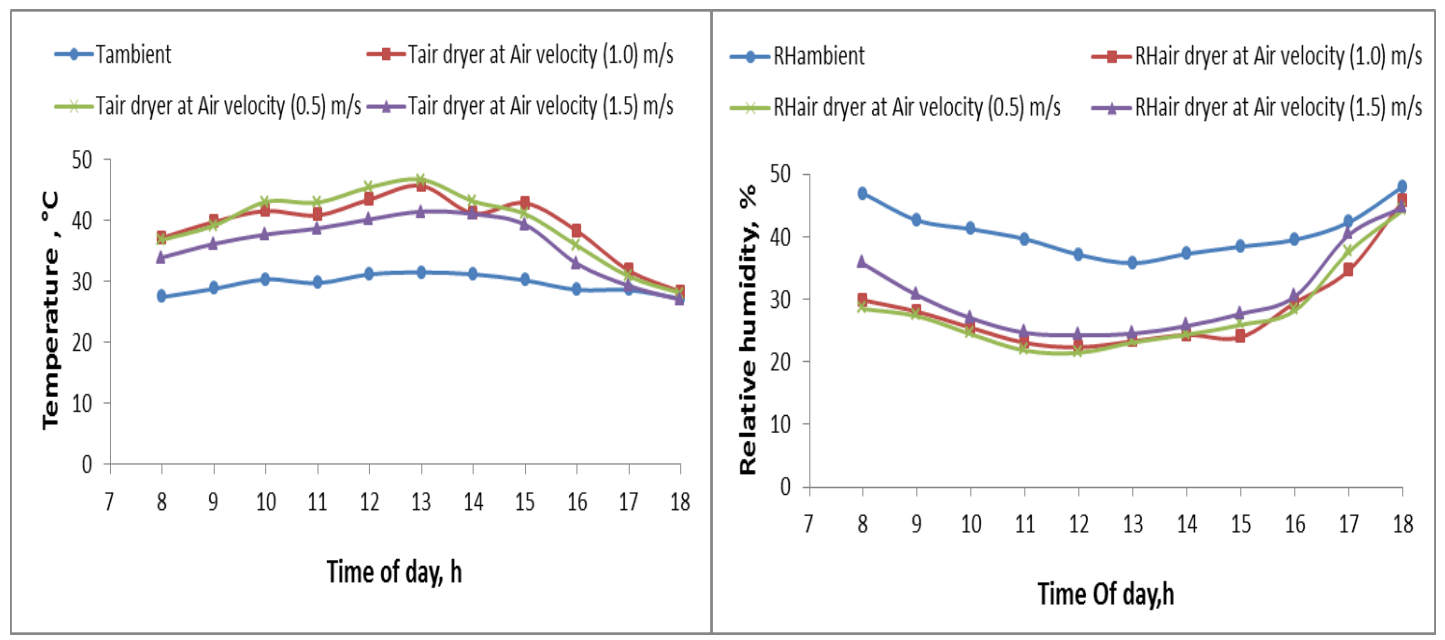

Fig. 6. Average air temperature and relative humidity inside and outside the dryer during the period of drying shelled corn.

\section{Grain bulk temperature}

Bulk temperature of ear and shelled corn was measured at different positions of drying bed. Figs. (7 and 8) illustrate the average bulk temperature for ear corn recorded $42.49,40.56$ and $38.63^{\circ} \mathrm{C}$ for air velocity $0.5,1.0$ and $1.5 \mathrm{~m} / \mathrm{s}$ respectively. The corresponding values for shelled corn recorded 38.06, 38.32 and $34.39{ }^{\circ} \mathrm{C}$. These differences in bulk temperatures could be attributed to the variation in ambient air temperature and air dryer temperature. The daily average grain bulk temperature for ear and shelled corn under natural sun drying during the drying period recorded 31.53 and $28.09^{\circ} \mathrm{C}$ respectively. The observed difference in grain bulk temperature inside and outside the dryers could be attributed to the solar dryer effect.

\section{Grain moisture content}

The drying rate and the reduction in moisture content of grain were varied with air velocity, air dryer temperature and corn condition. Grain moisture content of ear corn decreased from an initial level of 31.73 to final level of $14.07 \%$ (d.b.) in 26 , 24,28 and 46 hours with drying rate of 0.784 , $0.853,0.674$ and $0.491 \mathrm{~kg} / \mathrm{h}$ for solar drying at air velocities of $0.5,1.0,1.5 \mathrm{~m} / \mathrm{s}$ and natural sun drying respectively, as shown in Fig. (9). For shelled corn, grain moisture content decreased from an initial level of $27.23 \%$ to final level of $14.12 \%$ (d.b) in 20, 16,24 and 38 hours with drying rate of $0.699,0.850,0.627$ and $0.427 \mathrm{~kg} / \mathrm{h}$ for solar drying at air velocities $0.5,1.0,1.5 \mathrm{~m} / \mathrm{s}$ and natural sun drying respectively as shown in Fig. (10). Increasing the air velocity passing through the drying beds increased the drying rate and decreasing the drying time up to the level of $1.0 \mathrm{~m} / \mathrm{s}$ and then decreased with increasing air velocity to level of 1.5 $\mathrm{m} / \mathrm{s}$ as a result of the reduction in air temperature. 


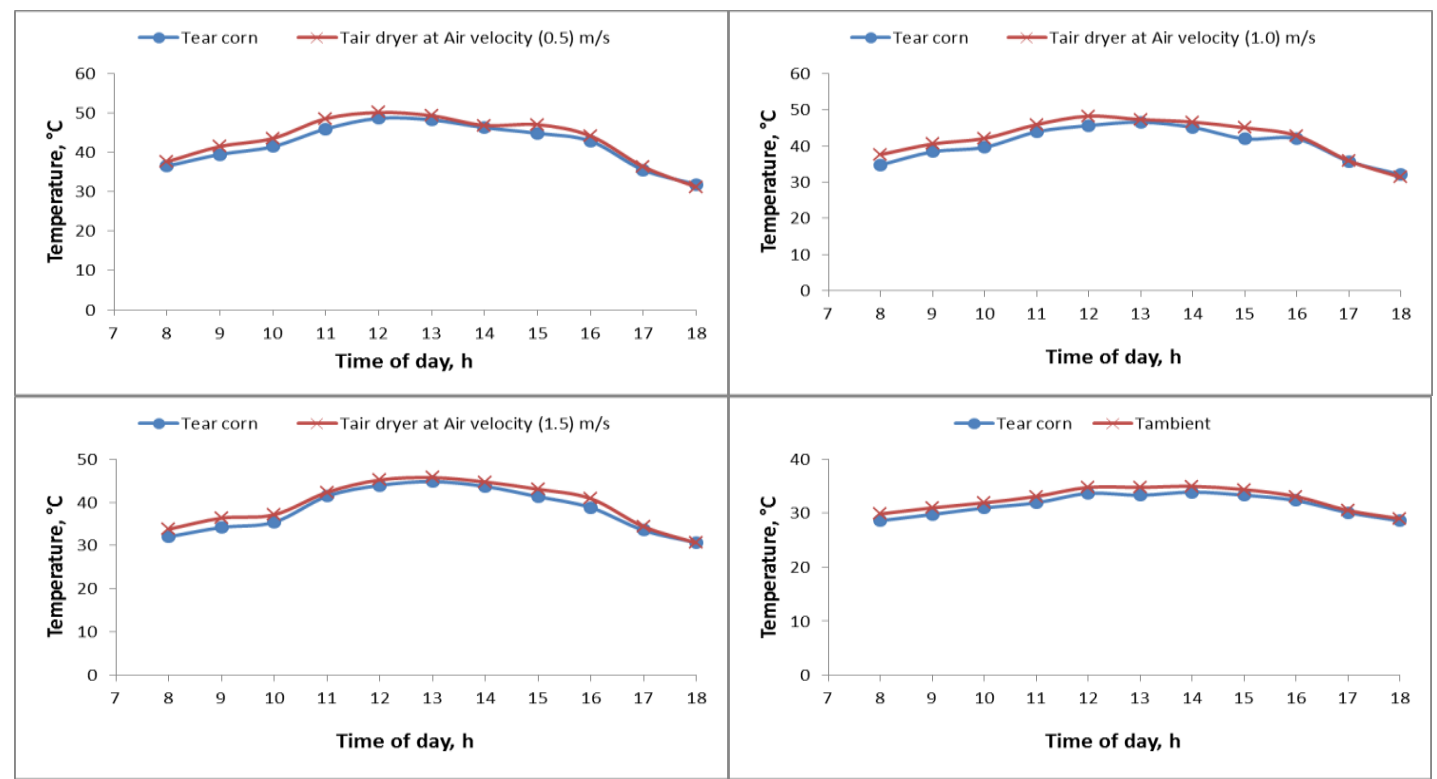

Fig. 7. Average bulk temperature during the period of ear corn drying

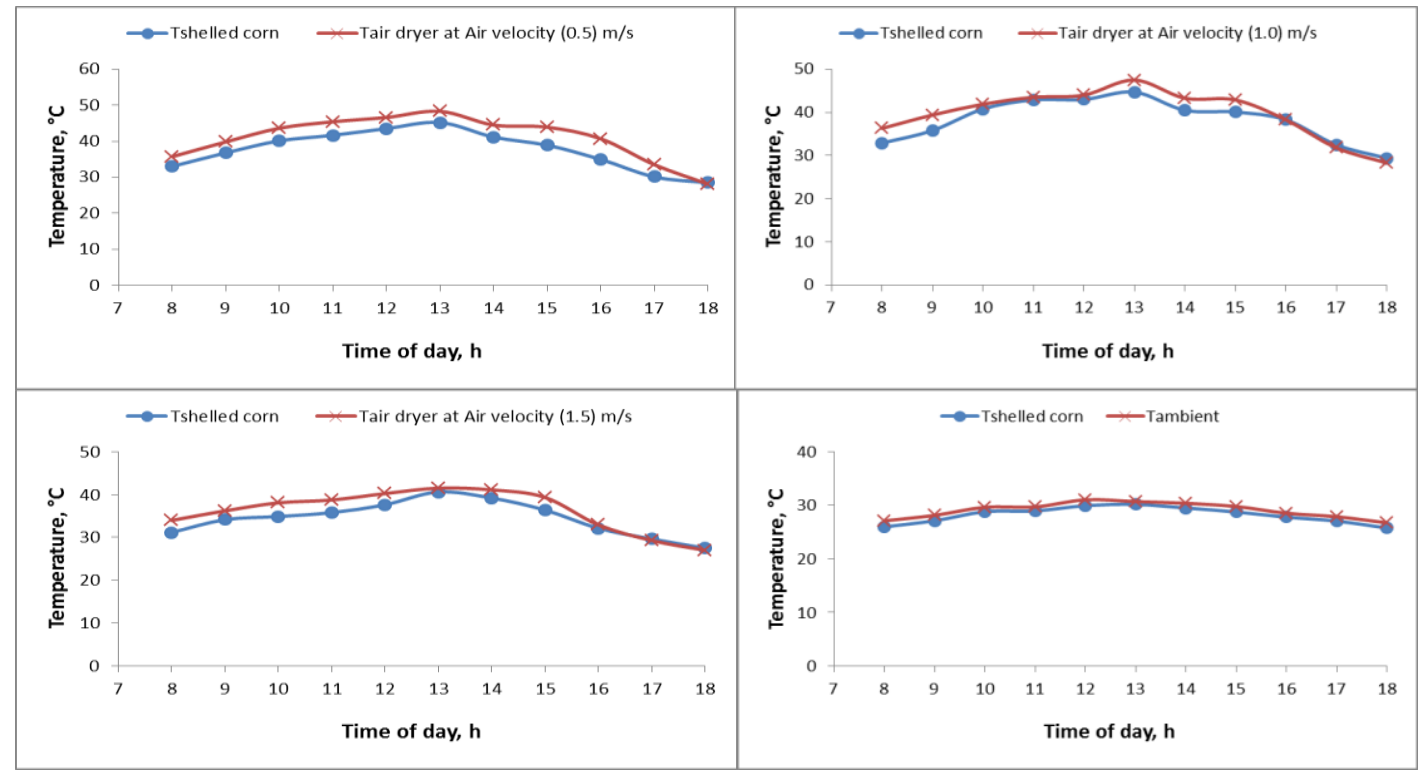

Fig. 8. Average bulk temperature during the period of shelled corn drying. 


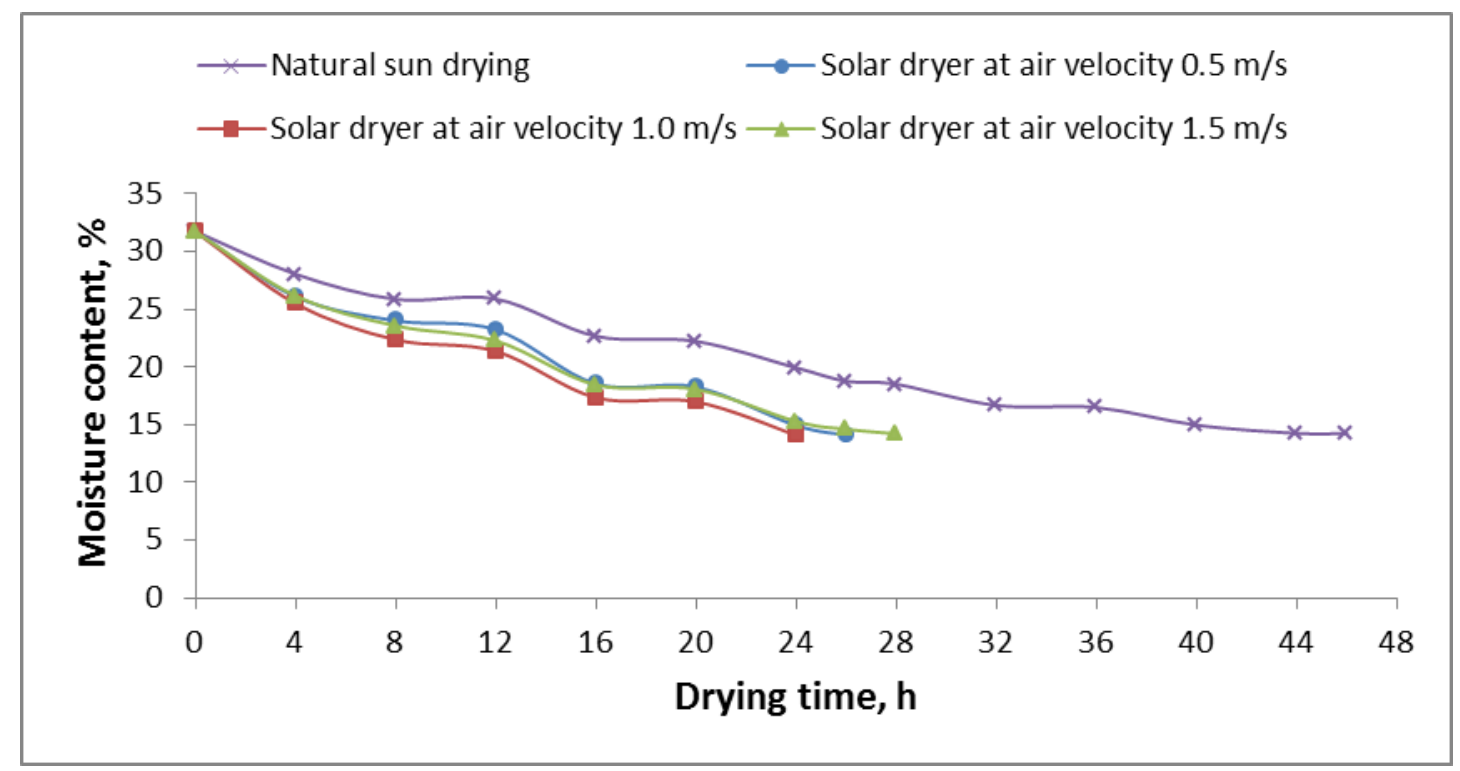

Fig. 9. Reduction in grain moisture content during ear corn drying.

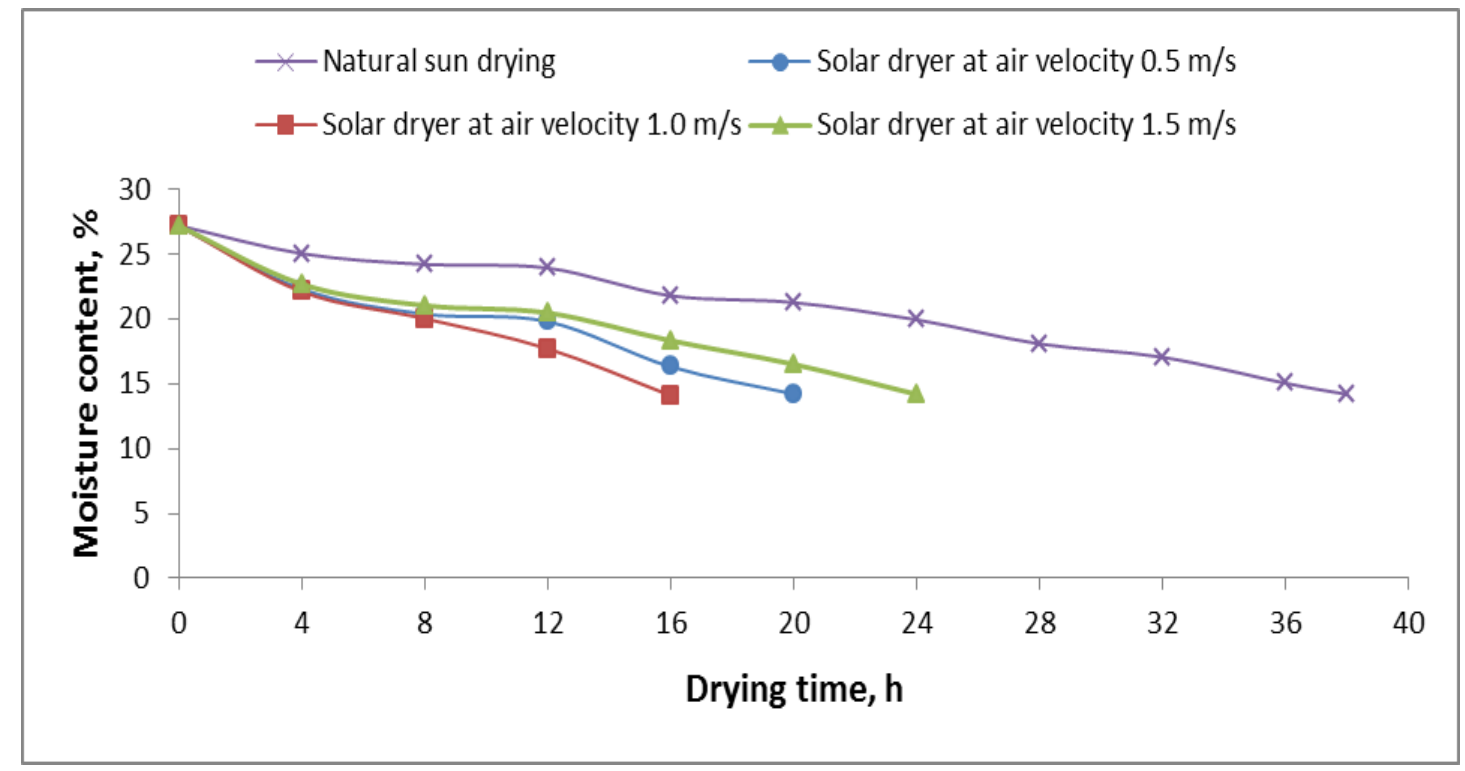

Fig. 10. Reduction in grain moisture content during shelled corn drying. 


\section{Drying efficiency}

The thermal energy utilized in the drying process varied from day to day during the experimental period according to the solar energy available and the initial moisture content of grain. As shown in Fig. (11). The average daily drying efficiency recorded $18.28,19.92$ and $17.01 \%$ at air velocity $0.5,1.0$ and $1.5 \mathrm{~m} / \mathrm{s}$, respectively compared with $8.75 \%$ for natural sun drying of ear corn. The corresponding values for shelled corn were $19.57,21.09$ and $18.90 \%$, respectively compared with $9.19 \%$ for natural sun drying of shelled corn. This is due to the difference in mass flow rate of drying air and the initial moisture content of grain.

Solar dryer operated at air velocity of $0.5 \mathrm{~m} / \mathrm{s}$, the average daily thermal efficiency was increased by $108.9 \%$, the corresponding values at air velocities of 1.0 and $1.5 \mathrm{~m} / \mathrm{s}$ were $127.7 \%$ and $94.4 \%$ compared with natural sun drying method during ear corn drying. The corresponding values during drying shelled corn were $112.9 \%, 129.5 \%$ and $105.7 \%$ at air velocities $0.5,1.0$ and $1.5 \mathrm{~m} / \mathrm{s}$, respectively. This is may be due to the largest total heat energy used in solar drying process of corn and the solar energy incident in dryer was reduced compared with available solar energy.

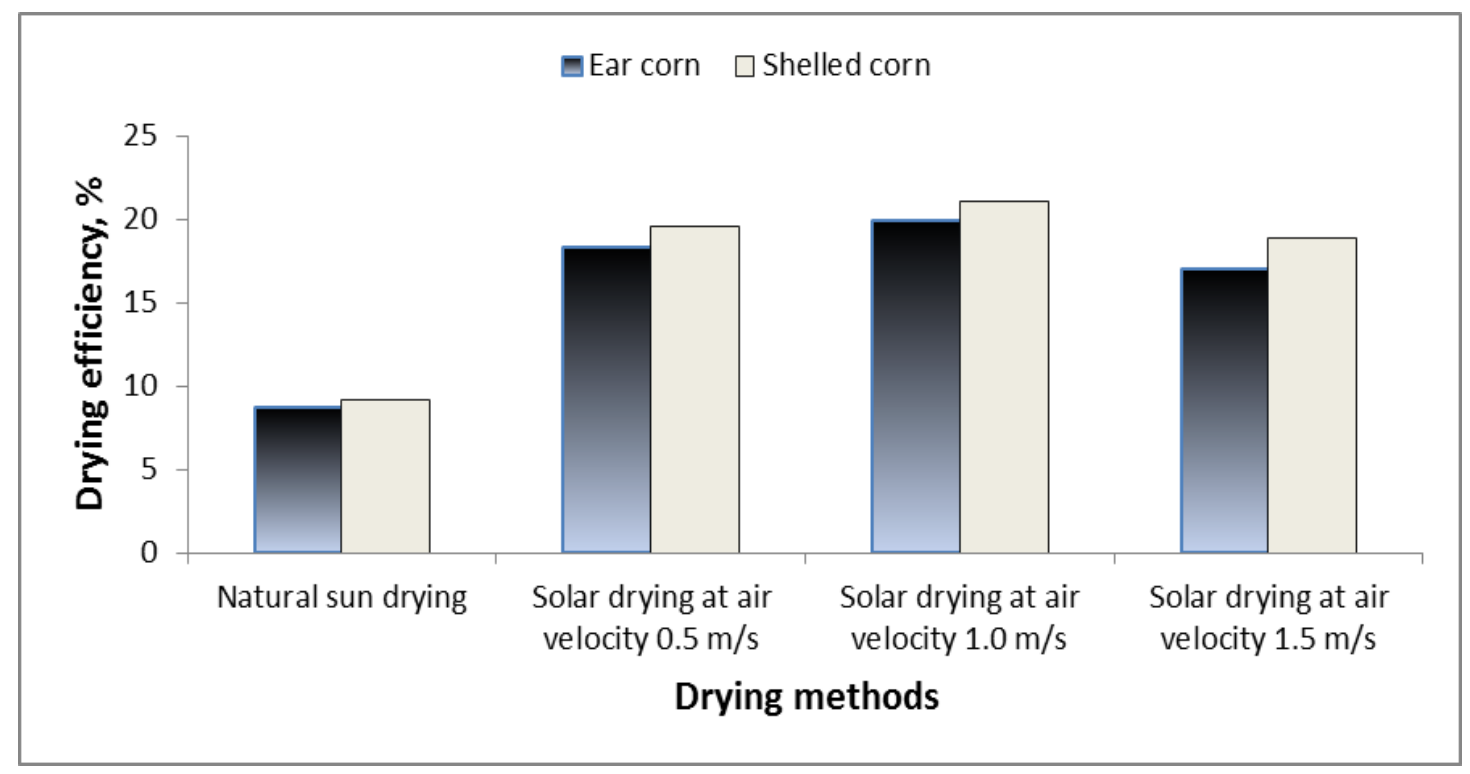

Fig. 11. Daily drying efficiency of natural sun drying and solar drying methods during the experimental work.

\section{Quality evaluation tests of dried grain}

The results of grain germination test, vigor test and tetrazolium test (viability) of dried grain of both ear and shelled corn for solar drying at air velocities of $0.5,1.0$ and $1.5 \mathrm{~m} / \mathrm{s}$ in comparison with natural sun drying are summarized and listed in Table (2).

It is observed that, solar drying method for ear corn at air velocities of 0.5 and $1.0 \mathrm{~m} / \mathrm{s}$ gave low level of grain germination, grain vigor and grain viability percentages. This could be attributed to high drying air temperature, while the average air temperature during solar drying of ear corn at air velocities 0.5 and $1.0 \mathrm{~m} / \mathrm{s}$ was 43.89 and $42.39{ }^{\circ} \mathrm{C}$. This level of drying air temperature exceeded the recommended level temperature for drying maize $\left(42-43{ }^{\circ} \mathrm{C}\right)$ as mentioned by FAO (1982). High temperatures could kill the germ so the dried grain non-viable for seeds production. 
Table 2. Standard germination test, vigor test and tetrazolium test for dried grain.

\begin{tabular}{|c|c|c|c|c|c|}
\hline Corn condition & \multicolumn{2}{|c|}{ Drying methods } & $\begin{array}{c}\text { Standard } \\
\text { germination } \\
\text { test, } \%\end{array}$ & vigor test, \% & $\begin{array}{c}\text { Tetrazolium } \\
\text { test, } \%\end{array}$ \\
\hline \multirow{5}{*}{$\begin{array}{l}\text { Ear } \\
\text { Corn }\end{array}$} & \multicolumn{2}{|c|}{ Natural sun drying } & 97 & 90 & 98 \\
\hline & \multirow{4}{*}{$\begin{array}{l}\text { Solar } \\
\text { drying }\end{array}$} & $0.5 \mathrm{~m} / \mathrm{s}$ & 79 & 34 & 83 \\
\hline & & 1.0 & 81 & 45 & 87 \\
\hline & & & & & \\
\hline & & $1.5 \mathrm{~m} / \mathrm{s}$ & 89 & 66 & 95 \\
\hline \multirow{5}{*}{ Shelled corn } & \multicolumn{2}{|c|}{ Natural sun drying } & 95 & 82 & 99 \\
\hline & \multirow{4}{*}{$\begin{array}{l}\text { Solar } \\
\text { drying }\end{array}$} & $0.5 \mathrm{~m} / \mathrm{s}$ & 93 & 86 & 98 \\
\hline & & 1.0 & 97 & 96 & 100 \\
\hline & & $\mathrm{m} / \mathrm{s}$ & & & \\
\hline & & $1.5 \mathrm{~m} / \mathrm{s}$ & 98 & 97 & 100 \\
\hline
\end{tabular}

\section{Cost analysis}

The hourly costs of drying are presented in Table (3) for ear and shelled corn for solar drying method at air velocities $0.5,1.0$ and $1.5 \mathrm{~m} / \mathrm{s}$ in comparison with natural sun drying method.

Table 3. The hourly costs, $(\mathrm{L} . \mathrm{E} / \mathrm{Kg})$ for natural sun drying and solar methods

\begin{tabular}{|c|c|c|c|c|}
\hline \multirow{2}{*}{$\begin{array}{c}\text { Drying } \\
\text { method }\end{array}$} & Natural & \multicolumn{3}{|c|}{ Solar drying } \\
\cline { 3 - 5 } sun drying & $\begin{array}{c}\mathbf{0 . 5} \\
\mathbf{m} / \mathbf{s}\end{array}$ & $\begin{array}{c}\mathbf{1 . 0} \\
\mathbf{m} / \mathbf{s}\end{array}$ & $\begin{array}{c}\mathbf{1 . 5} \\
\mathbf{m} / \mathbf{s}\end{array}$ \\
\hline $\begin{array}{c}\text { Ear corn } \\
\text { Shelled } \\
\text { corn }\end{array}$ & 1.03 & 0.95 & 0.88 & 1.00 \\
\hline
\end{tabular}

However, corn solar drying as shelled corn consumed more electricity and more labour as mentioned in Table (1), thus estimated drying cost was decreased. This could be attributed to the increasing the drying rate of shelled corn.

\section{CONCLUSION}

1. Solar drying process offers short drying time, high daily drying efficiency, but natural sun drying process offers long drying time, Low daily drying efficiency and high grain germination but about $30 \%$ losses due to rodents, birds and insects.

2. Increasing air temperature during the drying period up to $42^{\circ} \mathrm{C}$ decreased the grain germination.

3. Increasing the air velocity passing through the drying beds increased the drying rate, daily drying efficiency and decreasing total cost of drying and the drying time up to the level of 1.0 $\mathrm{m} / \mathrm{s}$ and then the drying rate and daily drying efficiency decreased and drying time and total cost of drying increased with increasing air velocity to level of $1.5 \mathrm{~m} / \mathrm{s}$.

4. Sun and solar drying of shelled corn reduced drying time, exposure period to hot air and increasing grain germination.

\section{REFERENCES}

Ajay, C., Somani, S.K. and Road A., 2009. "Design of Solar Dryer with Turbo ventilator and fireplace", International Solar Food Processing Conference. India, pp. 149-171.

AOAC 1990. "Official methods of analysis $\left(15^{\text {th }}\right.$ Ed)", Association of official analytical chemists, Washington DC.

Aravindh, M. A., and Sreekumar A., 2015. "Solar drying- A sustainable way of food processing in energy sustainability through green energy", Springer India, pp. 27-46. 
ASHRRAE Handbook Fundamentals, 2005. "American Society of Heating" , Refrigerating and Air-conditioning Engineers, Inc."

AOSA, 1986. "Rules for testing seeds", J. Seed Technol. 6(2), 1-12.

Ministry of Agriculture and land reclamation, 2015. Economic affair sector, Bulletin of the agricultural statistics, part (2), summer and nili crops.

El-Kholy, M.M. 2003. Development and evaluation of a natural convection solar dryer", J. Agric. Sci., Mansoura Univ., 28(5), 3967-3982.

FAO 1982. "Technical guideline for maize seed technology", 99 p.

FengWei, Z., KePing D., WuYun Z., Fene W., YongZhong F. and ZhengSheng H., 2010. "Design of ear maize solar heating air aerationdrying system based on two-stage drying process". Transaction of Chinese Society of Agric. Engineering, 26(8), 338-342.

Filed Crops Research Institute, Maize Research Section, 2014. "Annual Report", Agricultural Research Center, Egypt.

Gebreil, R.K. 2008. " Rough rice drying by infrared radiation" Ph.D. Thesis. Agric. Eng. Dept., Faculty of Agric., Suze Canal University. 45 p.

Hellevang, K. 2011. " Corn Drying and Storage Tips for 2011", Ph.D., Extension Service, Ag \& Bio systems Engineering Dept., pp. 1-9.

ISTA Working Sheets, 2011. "Tetrazoluim Testing", Agricultural, vegetable and horticultural species with supplements, Vol. I, 421 p..

Kamal, O.M. and El-Kholy M.M. 2002. "Development and evaluated of a greenhouse type solar dryer for drying ear and shelled corn". Egyptian J. of Agric. Research, 80(3), 12771294.
Kamel, O.M. 1991." Utilization of solar energy in agricultural crops drying", Unpublished M. Sc. Thesis. Mech. Eng. Dept. Faculty of Eng. University of Al-Azhar, Egypt. pp. 26-30.

Kiremire, B.T., Musinguzi E., Kikafunda J.K. and Lukwago F.B. 2010. " Effects of vegetables drying technique on nutrient content", African J. of Food, Agric., Nutrition and Development, 10(5), 2587-2600.

Meiering, A.G., Daynard, T.B., Browen R. and Otten L., 1977. "Drier performance and use energy in corn drying", Can. Agric. Eng. 19, 49-54.

Mohamed, A.T. 2000." New aspects in drying engineering of maize crop", Unpublished M. Sc. Thesis. Agric. Eng. Dept, Faculty of agric., Mansoura University, Egypt. pp. 41-46.

Peplinski, A.J., Paulsen, M.R., Anderson, R.A. and wolek W.F.K. 1989. "Physical, chemical and dry-milling characteristics of corn hybirds from various genotypes", Cereal Chem., 66(2), 117-120.

Reeb, J. and Milota, M. 1999. "Moisture content by oven-dry method for industrial testing". WDKA, pp. 66-74.

Sharma, A., Chen C.R. and Lan N.V. 2009. "Solar-energy drying systems: A review", Renewable and Sustainable Energy Reviews. 13, 1185-1210.

Sturton, S.L., Bilanski, W.K. and Menzies, D.R. 1981. "Drying of cereal grains with the dessicant bentonite", Can. Agric. Eng. 23, 101103.

Vijaya, S.V., Iniyan, S. and Ranko, G. 2012. "A review of solar drying technologies", Renewable and Sustainable Energy Reviews, 16, 2652-2670. 